\title{
PENGARUH BIAYA, ANGSURAN DAN KUALITAS PELAYANAN TERHADAP KEPUASAN NASABAH PEMBIAYAAN BMT AT-TAQWA MUHAMMADIYAH CABANG SITEBA PADANG
}

\author{
Budi Rahmatul HudaNazaruddin Aziz \\ Sekolah Tinggi Ilmu Ekonomi "KBP" \\ nazaruddinaziz@akbpstie.ac.id
}

\begin{abstract}
BMT is a micro finance institution that serves as an intermediary institution by collecting excess public funds to be channeled to communities in need of funds. Funds are made through savings made by pick up the ball, which is to take directly to the place of business customers regularly daily, weekly, and yearly. In this research, the research describes several variables that affect customer satisfaction that is cost, installment, service quality. Cost, installment, service quality is called with independent variable and customer satisfaction is called by bound variable. Through the research results obtained by researchers, the researchers draw the conclusion that through the F test explain the independent variables affect simultaneously to customer satisfaction because the sig value $<0,05$. While for independent variables tested individually through $T$ test explain all independent variables significantly affect customer satisfaction by looking at the value of sig $0.000<0,05,0.000<0,05$ sig installment and sig value of service quality $0,001<0,005$.
\end{abstract}

Keyword: Cost, Installment, Service Quality and Customer Satisfaction

\section{PENDAHULUAN}

Untuk mengatasi persoalan permodalan UMKM di Indonesia, lembaga keuangan mikro syariah (LKMS)dalam hal ini koperasi jasa keuangan syariah atau Baitul Maal Wat Tamwil (BMT) turut mengambil peran penting dalam pemberdayaan usaha kecil (Wardiwiyono, 2012). Ada beberapa alasan mengapa lembaga keuangan mikro syariah memiliki peranpenting dalam perberdayaan usaha kecil: pertama, keberadaan lembaga keuangan mikro syariah yang dekat dengan usaha kecil. Keberadaan BMT di lingkungan masyarakat terutama di daerah pinggiran, di tengah pasar atau di daerah pedesaan menjadikan akses usaha kecil lebih mudah karena tidak perlu ke kota dimana perbankan berada. Kedua, BMT yang berada di pedesaan atau pinggiran biasanya memiliki karyawan yang berasal dari daerah sekitar, hal ini memudahkan BMTdalam memberikan pinjaman atau pembiayaan karena kepada usaha kecil yang merupakan tetangga atau masyarakat dimana karyawan tinggal, sehingga memudahkan dalam menentukan kelayakan mana pengusaha kecil yang baik dan jujur dan mana yang tidak. Hal ini juga terkait dengan kecepatan dalam pencairan dana pinjaman. Ketiga, keterbatasan permodalan di BMT sesuai dengan kebutuhan permodalan di 
usaha kecil, sehingga kebutuhan untuk pengembangan usaha kecil bisa dipenuhi dengan pinjaman yang ada di BMT (Widiyanto dan Ismail, 2007; Wardiwiyono, 2012).

BMT merupakan usaha yang memiliki dua misi yaitu: misi sosial dan misi bisnis. Misi sosial merupakan fungsi baitul maal dari BMT dengan menghimpun dana: zakat, wakaf, infak dan shodaqoh untuk didistribusikan kepada masyarakat yang membutuhkan. Pemanfaatan dana ini bisa dalam bentuk dana produktif maupun dana konsumtif. Penggunaan untuk produktif dengan membiayai pendirian atau pengembangan usaha kecil sehingga menciptakan entrepreneurentrepreneur baru berasal dari masyarakat yang tidak memiliki modal maupun agunan untuk dijadikan jaminan bank. Pemberdayaan melalui baitul maal ini akan mendorong calon calon pengusaha untuk merintis usaha atau mengembangkan yang sudah ada dengan tanpa membebani dengan bagi hasil atau bunga yang harus ditanggung. Setelah usaha yang dirintis berjalan dengan baik dan mampu membayar pinjaman maka dana ini digulirkan kepada pengusaha lainnya yang membutuhkan pembiayaan (Azis, 2004).

Sedangkan fungsi kedua dari BMT adalah baitul tamwil yang mengemban tujuan bisnis untuk mendapatkan keuntungan.Fungsi ini sebagai lembaga intermediasi antara yang kelebihan dana dan fihak yang membutuhkan dana. Fungsi ini hampir mirip dengan usaha yang dijalankan perbankan yang menghimpaun dana dari masyarakat dan menyalurkannya kepada sektor riil dan bisnis yang halal dan menguntungkan. Fungsi ini menjadi fungsi yang dominan yang dilakukan BMT sekarang ini, meskipun demikian, BMT dianggap telah membantu mengatasi kemisninan dengan memberi pinjaman dalam jumlah yang kecil dan jumlah yang cukup banyak (Rokhman, 2013) karena mayoritas nasabah pembiayaan BMT di Indonesia merupakan pedagang kecil sebesar 63,7 persen, sedangkan di Jawa Tengah mayoritas sebesar 73,5 persen, sisanya pegawai dan petani (Sakti, 2013).

BMT merupakan lembaga keuangan mikro yang berfungsi sebagai lembaga intermediasi dengan mengumpulkan dana masyarakat yang kelebihan untuk disalurkan kepada masyarakat yang membutuhkan dana. Perhimpunan dana dilakukan melalui tabungan yang dilakukan dengan model jemput bola, yaitu mengambil langsung ke tempat usaha nasabah secara regular baik harian, mingguan, maupun tahunan. Disamping tabungan, BMT juga memberi fasilitas pengumpulan dana zakat, infak, shodaqoh dan wakaf untuk disalurkan kepada mustahiq (orang yang berhak menerima) baik untuk usaha konsumtif maupun usaha produktif (Widiyanto, 2007; Sebel dan Agung, 2008).

\section{Pengertian Biaya}

Biaya dapat dipandang sebagai suatu nilai tukar yang dikeluarkan atau suatu pengorbanan sumber daya yang dilakukan untuk mendapatkan manfaat di masa datang.Pengorbanan tersebut dapat berupa uang atau materi lainnya yang setara nilainya kalau diukur dengan uang. Dalam pengertian lebih jauh lagi, biaya (cost)dapat dipisahkan menjadi aktiva atau assets (unexpired cost) dan biaya atau expenses (expired cost). Biaya dianggap sebagai "assets" apabila biaya tersebut belum digunakan untuk menghasilkan produk atau jasa atau belum habis digunakan, sedangkan biaya dianggap sebagai "expenses" jika biaya tersebut habis digunakan untuk operasional yang menghasilkan pendapatan dalam suatu periode akuntansi. 
Biaya sebagai assets dicantumkan dalam neraca, sedangkan biaya sebagai expenses dicantumkan dalam laporan laba-rugi. Selanjutnya Muqodim (2005 : 142) mengatakan bahwa : "Biaya adalah aliran keluar atau penggunaan aktiva, atau terjadinya utang (atau kombinasi di antara keduanya) dari penyerahan atau produksi barang, penyerahan jasa atau pelaksanaan kegiatan utama suatu perusahaan."Biaya merupakan kas atau nilai setara dengan kas yang dikorbankan untuk barang dan jasa yang diharapkan dapat memberikan manfaat pada saat ini atau masa mendatang bagi organisasi, disebut setara dengan kas karena sumber daya non kas dapat ditukarkan dengan barang atau jasa yang dikehendaki.Biaya berkaitan dengan segala jenis organisasi bisnis, non bisnis, jasa, eceran dan pabrikasi yang sering diukur dengan satuan-satuan moneter (rupiah atau dollar) yang mesti dibayar untuk barang dan jasa.

2. Pengertian Angsuran

Salah satu keunggulan BMT adalah fleksibilitas dalam menampung dana dan menyalurkan dana melalui pembiayaan. Hal ini disebabkan karena kedekatan hubungan antara nasabah dan BMT, kedekatan ini disebabkan karena karyawan BMT yang terjun langsung ke lapangan menjemput calon nasabah baik penabung maupun nasabah pembiayaan.Disamping itu, mayoritas kantor-kantor BMT berada di sekitar pasar-pasar tradisional, sehingga memudahkan para pedagang pasar untuk menabung atau mengajukan pembiayaan (Sakti, 2013).

Dalam pengelolaan pembiayaan, BMT diuntungkan dengan pelayanan jemput bola karena pengajuan pembiayaan dapat dilakukan dengan cara yang cepat dan mudah oleh pedagang. Karyawan BMT yang setiap hari berinteraksi langsung dengan pedagang pasar akan sangat mudah menentukan apakah seorang pedagang layak diberi pembiayaan atau tidak berdasarkan analisis pengamatan lapangan yang selalu dilakukan. Proses ini cukup efektif dalam menyalurkan pembiayaan karena disalurkan kepada nasabah yang dianggap amanah dan bertanggung jawab. Hal ini berdampak positif bagi BMT karena memiliki nasabah pembiayaan yang baik, dengan angsuran yang lancar.

3. Pengertian Kualitas Layanan

Kualitas merupakan suatu kondisi dinamis yang berpengaruh dengan produk, jasa, manusia, proses dan lingkungan yang memenuhi atau melebihi harapan (Tjiptono, 2001). Sehingga definisi kualitas pelayanan dapat diartikan sebagai upaya pemenuhan kebutuhan dan keinginan konsumen serta ketepatan penyampaiannya dalam mengimbangi harapan konsumen (Tjiptono, 2007).Kualitas pelayanan (service quality) dapat diketahui dengan cara membandingkan persepsi para konsumen atas pelayanan yang nyata-nyata mereka terima / peroleh dengan pelayanan yang sesungguhnya mereka harapkan / inginkan terhadap atribut-atribut pelayanan suatu perusahaan. Jika jasa yang diterima atau dirasakan (perceived service) sesuai dengan yang diharapkan, maka kualitas pelayanandipersepsikan baik dan memuaskan, jika jasa yang diterima melampaui harapan konsumen, maka kualitas pelayanan dipersepsikan sangat baik dan berkualitas.Sebaliknya jika jasa yang diterima lebih rendah daripada yang diharapkan, maka kualitas pelayanan dipersepsikan buruk.

Menurut Kotler (2002:83) definisi pelayanan adalah setiap tindakan atau kegiatan yang dapat ditawarkan oleh suatu pihak kepada pihak lain, yang pada dasarnya tidak berwujud dan tidak mengakibatkan kepemilikan apapun. Produksinya dapat dikaitkan atau tidak dikaitkan pada satu produk fisik.Pelayanan 
merupakan perilaku produsen dalam rangka memenuhi kebutuhan dan keinginan konsumen demi tercapainya kepuasan pada konsumen itu sendiri.Kotler juga mengatakan bahwa perilaku tersebut dapat terjadi pada saat, sebelum dan sesudah terjadinya transaksi.

4. Kepuasan Nasabah

Menurut Kotler dan Armstrong (2001:9),Kepuasan konsumen adalah sejauh mana anggapan kinerja produk memenuhi harapan pembeli. Bila kinerja produk lebih rendah ketimbang harapan pelanggan, maka pembelinya merasa puas atau amat gembira.Kepuasan konsumen adalah sejauh mana manfaat sebuah produk dirasakan (perceived) sesuai dengan apa yang diharapkan pelanggan (Amir, 2005). Kotler (2000) mengatakan bahwa kepuasan konsumen merupakan tingkat perasaan seseorang setelah membandingkan antara kinerja produk yang ia rasakan dengan harapannya. Kepuasan atau ketidakpuasan konsumen adalah respon terhadap evaluasi ketidaksesuaian atau diskonfirmasi yang dirasakan antara harapan sebelumnya dan kinerja aktual produk yang dirasakan setelah pemakaian (Tse dan Wilson dalam Nasution, 2004)

Menurut Zeithaml dan Bitner (2000:75), definisi kepuasan adalah Respon atau tanggapan konsumen mengenai pemenuhan kebutuhan. Kepuasan merupakan penilaian mengenai ciri atau keistimewaan produk atau jasa, atau produk itu sendiri, yang menyediakan tingkat kesenangan konsumen berkaitan dengan pemenuhan kebutuhan konsumsi konsumen.

Menurut pasuraman, zeithaml,dan Berry(6) mengemukakan bahwa kepuasan pelanggan adalah perasaan pelanggan terhadap satu jenis yang didapatkannya.

Menurut Philip Kotler dan Kevin Lane Keller yang dikutip dari buku Manajemen Pemasaran mengatakan bahwa Kepuasan Konsumen adalah perasaan senang atau kecewa seseorang yang muncul setelah membandingkan kinerja (hasil) produk yang dipikirkan terhadap kinerja yang diharapkan (2007:177).

Kepuasan konsumen adalah tingkat perasaan konsumen setelah membandingkan antara apa yang dia terima dan harapannya (Umar, 2005:65). Seorang pelanggan, jika merasa puas dengan nilai yang diberikan oleh produk atau jasa, sangat besar kemungkinannya menjadi pelanggan dalam waktu yang lama.Menurut Philip Kotler (2002: 42) "Kepuasan konsumen adalah perasaan senang atau kecewa seseorang yang berasal dari perbandingan antara kesannya terhadap kinerja (atau hasil) suatu produk dan harapan-harapannya".

Sedangkan menurut Zulian Yamit (2005: 78) "Kepuasan konsumen merupakan evaluasi purna beli atau hasil evaluasi setelah membandingkan apa yang dirasakan dengan harapannya". Dalam konsep kepuasan konsumen, terdapat dua elemen yang mempengaruhi yaitu harapan dan kinerja. Sedangkan Kotler (1997) dalam Saryadi dan Wahyuddin (2006) menyatakan bahwa kepuasan pelanggan adalah tingkat keadaan perasaan seseorang yang merupakan hasil perbandingan antara penilaian kinerja / hasil akhir produk dalam hubungan nya dengan harapan pelanggan.

\section{METODE PENELITIAN}

\section{Jenis Penelitian}

Berdasarkan permasalahan yang akan diteliti pada penelitian ini adalah penelitian kuantitatif yang bersifat kausatif dimana berbicara dengan angka-angka serta melihat pengaruh antara variabel bebas (independen) dengan variabel terikat 
(dependent) sugiyono (2009). Pada penelitian ini peneliti ingin menganalisis pengaruh biaya,angsuran dan kualitas pelayanan terhadap kepuasan nasabah pembiayaan BMT At-Taqwa Muhammadiyah cabang Siteba Padang.

\section{Populasi}

Populasi diartikan sebagai wilayah generalisasi yang terdiri atas objek/subjek yang mempunyai kualitas dan karakteristik tertentu yang diterapkan oleh peneliti untuk dipelajari dan karekteristik tertentu yang ditetapkan oleh peneliti untuk dipelajari dan kemudian ditarik kesimpulan nya (Sugiyono,2004). Adapun total populasi BMT At-Taqwa Muhammadiyah cabang Siteba Padang yaitu 122 nasabah, pada penelitian ini adalah nasabah BMT At-Taqwa Muhammadiyah cabang Siteba Padang.

\section{Sampel}

Namun karena keterbatasan penulis maka penelitian ini dilakukan terhadap sample yang dapat mewakili populasi. Pengambilan sample dilakukan dengan Rumus Taro Yamane. Rumus Taro Yamane digunakan untuk menentukan ukuran sampel dari populasi yang telah diketahui jumlahnya yaitu sebanyak 122 . Untuk tingkat presisi yang ditetapkan dalam penentuan sampel adalah $0.5 \%$.

Berdasarkan hasil perhitungan dengan menggunakan rumus Taro Yamane maka sampel yang dapat ditarik adalah 94 nasabah BMT At-Taqwa Muhammadiyah cabang Siteba Padang.

\section{HASIL PENELITIAN}

\section{Gambaran Umum Penelitian}

BMT Taqwa Muhammadiyah merupakan salah satu lembaga keuangan mikro syariah yang berbadan hukum koperasi dengan pola syariah. BMT At Taqwa Muhammadiyah Padang didirikan pada tanggal 9 September 1996. BMT At Taqwa Muhammadiyah mulai beroperasi dengan modal awal sebesar Rp. 2.701.000,- (dua juta tujuh ratus satu ribu rupiah) dengan fasilitas kantor di lingkungan Masjid Taqwa Muhammadiyah jalan Bundo Kandung No.1 Padang dengan perlengkapan seadanya yang dipersiapkan oleh badan pendiri yaitu Majelis Ekonomi Muhammadiyah Sumatera Barat.

BMT At-Taqwa Muhammadiyah Padang telah memiliki 7 cabang yang tersebar di Sumatera Barat. Salah satu cabang tersebut peneliti meneliti cabang yang berada di siteba padang.

Berdasarkan jenis kelamin menunjukkan bahwa jumlah responden laki-laki sebanyak $28,72 \%$, sementara untuk responden perempuan sebanyak $71,28 \%$. Hal ini menunjukkan bahwa nasabah perempuan lebih banyak daripada nasabah lakilaki.

Berdasarkan tabel 4.3 menunjukkan bahwa nasabah dengan kisaran umur 3237 tahun jumlahnya lebih dominan sebanyak 40,42\%. Sedangkan untuk umur responden yang paling kecil persentasi dalam pengisian kuesioner adalah $<25$ tahun sebanyak $0 \%$.

Berdasarkan tabel 4.4 menunjukkan bahwa nasabah dengan jenis pekerjaannya wiraswasta adalah sebanyak $51,06 \%$ Sedangkan untuk pekerjaan yang persentasenya rendah adalah pelajar sebanyak $0 \%$. Maka dengan melihat tabel identifikasi pekerjaan responden dapat disimpulkan bahwa pekerjaan wiraswasta lebih dominan dari pekerjaan yang lainnya. 
Berdasarkan tabel 4.5 menunjukkan bahwa konsumen dengan berpendapatan Rp 1.500.000 - 2.000.0000 adalah sebanyak 51,06\% Maka dengan melihat tabel identifikasi pendapatan responden dapat disimpulkan bahwa berpendapatan $\mathrm{Rp}$ 1.500.000 - 2.000.0000 lebih dominan dari pendapatan yang lainnya.

2. Uji Normalitas

Tujuan dari uji normalitas risidual adalah untuk menguji dalam sebuah model regresi, variabel dependen dan variabel independen terdistribusi secara normal atau tidak. Pengujian normalitas data dalam penelitian ini dilakukan dengan menggunakan one sample kolmogorov-smirnov test, yang mana jika nilai asymp.sig (2-tailed) > 0.05 maka distribusi data dikatakan normal.

Dari Tabel 4.18 terlihat bahwa nilai asymp.sig (2-tailed) menunjukkan nilai > dari 0.05, yaitu 0.270 Dengan demikian data dapat dikatakan berdistribusi normal. 3. Uji Heterokedastisitas

Dari Tabel 4.19 terlihat bahwa nilai sig menunjukkan nilai > dari 0.05 , itu dapat diartikan tidak terjadi heteroskedasitas yang mana pada variabel X1 0,877, X2 0,525 dan X3 0,685.

4. Uji Multikolineritas

Untuk menguji adanya multikolinearitas dapat dilihat melalui Variance Inflantion Factor (VIF) $<10$ dan tolerance $>0.1$. Variabel biaya (X1) dengan nilai VIF 5,559, variabel angsuran (X2) dengan nilai VIF 2,286, dan variabel kualitas pelayanan (X3) dengan nilai VIF 5,957. Pada variabel biaya (X1) dengan nilai tolerance 0,180 , variabel angsuran (X2) dengan nilai tolerance 0,437 , dan variabel kualitas pelayanan (X3) dengan nilai tolerance 0,168. Dengan demikian dapat dikatakan bahwa tidak terdapat korelasi variabel-variabel bebas antara satu dengan yang lainnya, atau variabel independent pada penelitian ini bebas multikolineritas.

5. Uji Regresi Berganda

Dari persamaan diatas dapat diambil kesimpulan bahwa:

1. Koefisien regresi biaya bernilai negatif yaitu $-0,477$. Hal ini berarti setiap peningkatan biaya sebesar satu satuan akan meningkatkan kepuasan nasabah adalah -0,477 satuan dengan asumsi variabel lain selain biaya adalah tetap atau tidak mengalami perubahan

2. Koefisien regresi angsuran bernilai positif yaitu 0,303. Hal ini berarti setiap peningkatan angsuran sebesar satu satuan akan mengakibatkan peningkatan kepuasan nasabah adalah 0,303 satuan dengan asumsi variabel lain selain angsuran adalah tetap atau tidak mengalami perubahan.

3. Koefisien regresi kualitas pelayanan bernilai positif yaitu 0,843 . Hal ini berarti setiap peningkatan kualitas pelayanan sebesar satu satuan akan mengakibatkan peningkatan kepuasan nasabah adalah 0,843 satuan dengan asumsi variabel lain selain kualitas nasabah adalah tetap atau tidak mengalami perubahan.

6. Uji Hipotesis

Nilai $F$ hitung adalah 652,234 sedangkan nilai sig adalah 0,000. Dengan demikian berarti $\mathrm{F}$ hitung $>\mathrm{F}$ tabel dan nilai sig $<\alpha 0,05$, yaitu $652,234>2,70$, dan sig $0,000<\alpha 0,05$. Hal ini menunjukkan bahwa model regresi dapat digunakan untuk menguji pengaruh secara bersama-sama variabel independen terhadap variabel dependen, yaitu biaya, angsuran dan kualitas pelayanan bersama-sama berpengaruh terhadap kepuasan nasabah. 
Pengujian hipotesis 1 dilakukan dengan membandingkan nilai t hitung dan $\mathrm{t}$ tabel. Hipotesis diterima jika $t$ hitung $>t$ tabel atau nilai sig $<\alpha 0,05$. Nilai $t$ tabel pada $\alpha=0,05$ adalah 1,661 . Untuk variabel biaya (X1) nilai t hitung adalah 4,444 atau nilai sig adalah 0,000. Dengan demikian dapat dikatakan bahwa t hitung $>\mathrm{t}$ tabel, yaitu 4,444 $>1,661$ atau nilai signifikansi $0,000<\alpha 0,05$. Nilai koefisien $\beta$ dari variabel $\mathrm{X} 1$ bernilai positif yaitu 0,303. Hal ini menunjukkan bahwa penelitian ini dapat membuktikan biaya (X1) berpengaruh signifikan dan positif terhadap kepuasan nasabah. Sehingga hipotesis pertama pada penelitian ini dapat diterima

Pengujian hipotesis 2 dilakukan dengan membandingkan nilai t hitung dan $\mathrm{t}$ tabel. Hipotesis diterima jika $\mathrm{t}$ hitung $>\mathrm{t}$ tabel atau nilai sig $<\alpha 0,05$. Nilai $\mathrm{t}$ tabel pada $\alpha=0,05$ adalah 1,661. Untuk variabel angsuran (X2) nilai t hitung adalah 18,918 atau nilai sig adalah 0,000. Dengan demikian dapat dikatakan bahwa t hitung $>$ t tabel, yaitu $18,918>1,661$ atau nilai signifikansi $0,000<\alpha 0,05$. Nilai koefisien $\beta$ dari variabel X2 bernilai positif yaitu 0,843 . Hal ini menunjukkan bahwa penelitian ini dapat membuktikan angsuran (X2) berpengaruh signifikan dan positif terhadap kepuasan nasabah. Sehingga hipotesis kedua pada penelitian ini dapat diterima

Pengujian hipotesis 3 dilakukan dengan membandingkan nilai t hitung dan $\mathrm{t}$ tabel. Hipotesis diterima jika $\mathrm{t}$ hitung $>\mathrm{t}$ tabel atau nilai sig $<\alpha 0,05$. Nilai $\mathrm{t}$ tabel pada $\alpha=0,05$ adalah 1,661. Untuk variabel kualitas pelayanan (X3) nilai t hitung adalah 3,507 atau nilai sig adalah 0,001. Dengan demikian dapat dikatakan bahwa $\mathrm{t}$ hitung $>\mathrm{t}$ tabel, yaitu 3,507 $>1,661$ atau nilai signifikansi $0,001<\alpha 0,05$. Nilai koefisien $\beta$ dari variabel X3 bernilai positif yaitu 0,231 . Hal ini menunjukkan bahwa penelitian ini dapat membuktikan kualitas pelayanan (X3) berpengaruh signifikan dan positif terhadap kepuasan nasabah. Sehingga hipotesis ketiga pada penelitian ini dapat diterima

Nilai Adjusted $R$ square menunjukkan 0,956. Hal ini mengindikasikan bahwa kontribusi variabel bebas yaitu biaya, angsuran dan kualitas pelayanan terhadap variabel terikat yaitu kepuasan nasabah 95,6\%, sedangkan 14,4\% ditentukan oleh faktor lain.

\section{PEMBAHASAN}

Berdasarkan hasil analisis statistik dalam penelitian ini ditemukan bahwa hipotesis pertama (H1) disimpulkan bahwa biaya mempunyai pengaruh signifikan terhadap kepuasan nasabah. Hal ini dapat dilihat dari nilai signifikansinya yaitu 0,000 (kecil dari $\alpha=0,05$ ). Ini dapat diartikan bahwa biaya dalam peminjaman kepada nasabah berpengaruh terhadap kepuasan nasabah sehingga nasabah tersebut secara periodik akan mengajukan peminjaman kembali.

Berdasarkan hasil analisis statistik dalam penelitian ini ditemukan bahwa hipotesis kedua (H2) disimpulkan bahwa angsuran mempunyai pengaruh signifikan dan postif terhadap kepuasan nasabah. Hal ini dapat dilihat dari nilai signifikansinya yaitu 0,000 (kecil dari $\alpha=0,05$ ). Ini dapat diartikan bahwa daftar angsuran yang ditunjukan dan dijelaskan kepada nasabah memberikan kepuasan tersendiri karena setelah mendengar penjelasan maka nasabah tersebut merasa tertarik untuk melakukan peminjaman.

Berdasarkan hasil analisis statistik dalam penelitian ini ditemukan bahwa hipotesis ketiga (H3) disimpulkan bahwa kualitas pelayanan mempunyai pengaruh 
signifikan dan positif terhadap kepuasan nasabah. Hal ini dapat dilihat dari nilai signifikansinya yaitu 0,001 (kecil dari $\alpha=0,05$ ). Ini dapat diartikan bahwa kualitas pelayanan merupakan hal yang penting dalam kepuasan nasabah.

\section{UCAPAN TERIMAKASIH}

Ucapan terima kasih untuk Bapak Febryandhie Ananda, SE, M.Si selaku Ketua Sekolah Tinggi Ekonomi "Keuangan, Perbankan dan Pembangunan" (STIE"KBP" Padang) beserta staf pimpinan, karyawan dan karyawati di STIE"KBP" Padang. Bapak Nazaruddin Azis, SE, MM selaku pembimbing. Bapak dan Ibu Dosen STIE"KBP" Padang yang telah membantu penulis selama menuntut ilmu yang bermanfaat kepada penulis selama perkuliahan. Teman-teman dan pihak lain yang membantu penulis dalam menyelesaikan skripsi ini yang tidak dapat penulis sebutkan satu persatu namanya.

\section{DAFTAR PUSTAKA}

Andika, A., \& Susanti, F. (2018). Pengaruh Marketing Mix Terhadap Keputusan Pembelian Parfum di Azzwars Parfum Lubeg Padang. https://doi.org/10.31227/osf.io/upgc3

Ashraf, M. A. dan Noor, M. S.I. (2010). Microfinance Customer (Borrower) Experience Towards The Effectiveness of MFIs In Bangladesh: An Exploratory Analysis. ABAC Journal, 30(2), 12-25.

Awojobi, O dan Murad Bein, M.A. (2011). Microfinancing for Poverty Reduction and Economic Development; a Case for Nigeria. International Research Journal of Finance and Economics, 1(72), 159-168.

Aziz, M.A. (2004). The Prospect of BMT in Indonesia, Centre for Small and Medium Enterprises Incubation (PINBUK), Jakarta.

Aziz, N. (2019). Pengaruh Strategi Promosi Terhadap Keputusan Pembelian Yang Dimediasi Oleh Minat Beli Pada Konsumen Restoran KFC Cabang Khatib Sulaiman Padang. https://doi.org/10.17605/OSF.IO/V92TS

Bashir, M. S., Machali, M. M., dan Mwinyi, A. M., (2012). The Effect of Service Quality and Government Role on Customer Satisfaction: Empirical Evidence of Microfinance in Kenya. International Journal of Business and Social Science, 3(14), 312-319.

Chowdhury, A. M. R., dan Bhuiya, A. (2004). The wider impacts of BRAC poverty alleviation programme in Bangladesh. Journal of International Development 16(3), 369-386.

Coleman, B.E. (1999). The Impact of group lending in Northeast Thailand.Journal of Development Economics, 60, 105-141.

Durrani, M.K.K., Usman, A., Muhammad Imran Malik, M.I., dan Ahmad, S. (2011). Role of Micro Finance in Reducing Poverty: A Look at Social 
and Economic Factors. International Journal of Business and Social Science, 2 (21), 138-144.

Fernandes, Y. D., \& Marlius, D. (2018). Peranan Customer Service Dalam Meningkatkan Pelayanan Kepada Nasabah Pada PT. Bank Pembangunan Daerah Sumatera Barat Cabang Utama Padang. https://doi.org/10.31227/osf.io/wrh3p

Gebru, B. dan Paul, I. (2011). Role of Microfinance in Alleviating Urban Poverty In Ethiopia. Journal Of Sustainable Development In Africa, 13(6), 165180.

Gurses, D. (2009). Micro-finance and Poverty Reduction in Turkey.Perspectives On Global Development and Technology, 8(1), 90-110.

Hasan, N.M., Mohd Nor, A.B dan Mohd Rom, A.A. (2012). Embracing Microfinance: Proposed collaboration between zakat Institution and Microfinance Institutions. 3rdInternational conference on Business and Economic Research Proceeding. Bandung, Indonesia.

Hassan, M.K. (2010). An Integrated Poverty Alleviation Model Combining Zakat, Awqaf and Micro-finance. Seventh International Conference (The Tawhidi Epistemology), 1-21.

Ikbal, M., \& Marlius, D. (2017). Pengaruh Jumlah Taksiran Dan Uang Pinjaman Terhadap Laba Bersih Pada PT. Pegadaian (UPC) Gurun Laweh. https://doi.org/10.31227/osf.io/uch4a

Jamarnis, S., \& Susanti, F. (2019). Pengaruh Harga Dan Periklanan Melalui Internet Terhadap Keputusan Pembelian Produk Sabun Merek Lux Pada Mahasiswa STIE “KBP” Padang. https://doi.org/10.31227/osf.io/xz3d8

Kanyurhi, E., B. (2013). Evaluation of customer satisfaction with services of a micro-finance institution: Empirical evidence from Women Association for Social and Economic Gain. African Journal of Marketing Management, 5(2), 26.

Kessy, S.A dan Urio, F. M. (2006).Contribution of Microfinance Institutions to poverty Reduction in Tanzania. sumber: http://www.repoa.or.tz/documents storage/Publications/Reports/06 Kessy and Urio.pdf

Khan, S., Naeem, A., dan Kasi, M., S. (2012). Micro Finance and Small Enterprises Development: Client perspective Study of Baluchistan, Pakistan. International Journal of Art and Commerce, 1(5), 279-292.

Khandker, S. (1998). Fighting poverty with microcredit: experience from Bangladesh. New York: Oxford University Press for the World Bank. 
Kotler, P. (2009). Manajemen Pemasaran. Jakarta : Erlangga

Marlius, D. (2018). Loyalitas Nasabah Bank Nagari Syariah Cabang Bukittinggi Dilihat Dari Kualitas Pelayanan. Jurnal Pundi. Volume 1. No. 3. Hal.1222. https://doi.org/10.31575/jp.v1i3.60

Marlius, D. (2018). Pengaruh Dimensi Kualitas Pelayanan Website Akademik Terhadap Kepuasan Mahasiswa Pada STIE "KBP". Jurnal Ipteks Terapan. Volume 12. No. 2. Hal. 116-128. http://doi.org/10.22216/jit.2018.v12i2.633

Marlius, D. (2017). Keputusan Pembelian Berdasarkan Faktor Psikologis Dan Bauran Pemasaran Pada PT. Intercom Mobilindo Padang. Jurnal Pundi. Volume 1. No. 1. Hal. 57-66. https://doi.org/10.31575/jp.v1i1.9

Marlius, D. (2016). Pengaruh Bauran Pemasaran Jasa Terhadap Minat Nasabah Dalam Menabung Pada Bank Nagari Cabang Muaralabuh. https://doi.org/10.31227/osf.io/vdqgx

Masyita, D., dan Ahmed, H. (2011). Why is Growth of Islamic Microfinance Lower than Conventional? : A Comparative Study of the Preferences and Perceptions of the Clients of Islamic and Conventional Microfinance Institutions' in Indonesia. Paper dipresentasikan di International Conference on Islamic Economics and Finance ke 8, Doha, Qatar. 19-21 Desember 2011.

Mayliza, R. (2019). Pengaruh Kesadaran Merek, Asosiasi Merek Dan Perception Of Quality Terhadap Keputusan Pembelian Hospital Bed Merek Paramout Di PT. Aga Medika Utama Padang (Studi Kasus Rumah Sakit Umum Kota Padang). https://doi.org/10.17605/OSF.IO/VYQ4E

Obaidullah M. dan Khan, T. (2008). Islamic Microfinance Development Challenges and Initiatives. Policy dialogue Paper No. 2, IRTI, Islamic Development Bank, Jeddah.

Okpara, G.C. (2010). Microfinance Banks and Poverty Alleviation In Nigeria, Journal Of Sustainable Development In Africa, 12(6), 177-191.

Rahman, M.M. (2010). Islamic micro-finance programme and its impacton rural poverty alleviation. International Journal of Banking and Finance, 7 (1), 119-138.

Rokhman, W. (2013). The Effect of Islamic Microfinance on Poverty Alleviation: Study In Indonesia. Economic Review: Journal of Economics and Business, 11(2), 21-30. 
Rokhman, W. dan Rivai, H.A. (2014). Evaluation of Customer Satisfaction on Islamic Microfinance: Empirical Evidence from Central Java, Indonesia, South Asian Journal of Management Sciences, 8(2), 60 - 69.

Safitri, R. N., \& Marlius, D. (2017). Penerapan E-Banking Dalam Meningkatkan Jasa Dan Layanan Perbankan Di PT. Bank Rakyat Indonesia Cabang Padang. https://doi.org/10.31227/osf.io/gkv8t

Sakai dan Marijan, (2008). Mendayagunakan pembiayaan mikro Islami. Publised by Crawford School of Economics and Government, Australian National University.

Sakti, A. (2013). Pemetaan Kondisi dan Potensi BMT: Kemitraan Dalam Rangka memperluas Pasar dan Jangkauan Pelayanan Bank Syariah kepada Usaha Mikro. Jurnal al-Muzara'ah, 1(1), 1-18.

Shirazi, N.S. dan Khan, A.U. (2009), Role of Pakistan Poverty Alleviation Fund's Micro Credit In Poverty Alleviation :A Case of Pakistan.Pakistan Economic and Social Review, 7(2), 215-228.

Siebel, H. D. dan Agung, W. D. (2005). Islamic Microfinance in Indonesia.Published by University of Cologne Development Center.

Soesastro, H dan Basri, M. K. (2005). The Political Economy of Trade Policy in Indonesia, Economics Working Paper Series, sumber: http://www.csis.or.id/papers/wpe092.

Suryahadi, A., Hadiwidjaja, G., dan Sumarto, S. (2012). Economic Growth and Poverty Reduction in Indonesia Before and After the Asian Financial Crisis.The SMERU Research Institute, Jakarta.

Susanti, F. (2015). Pengaruh Bauran Promosi Terhadap Keputusan Klien Dalam Memilih Radio Carano Sebagai Media Promosi Iklan. https://doi.org/10.31227/osf.io/b9ws7

Susanti, F. W Ekazaputri. (2018). Service Performance Dan Kepuasan Sebagai Moderating Variabel Terhadap Loyalitas Nasabah Pada PT BPR Labuh Gunung Payakumbuh Jurnal Benefita: Ekonomi Pembangunan Manajemen Bisnis Dan Akuntansi. Volume 3. No. 3. Hal. 433444.http://doi.org/10.22216/jbe.v3i3.3472

Susanti, F. (2014). Pengaruh Tarif Iklan Terhadap Pendapatan Pada PT. Radio Swara Carano Batirai Indah Batusangkar. https://doi.org/10.31227/osf.io/dy863

Susanti, F., \& Gunawan, A. C. (2019). Pengaruh Bauran Promosi Dan Harga Terhadap Keputusan Pembelian Produk Kosmetik Maybelline Di Kota Padang. https://doi.org/10.31227/osf.io/npjqh 
Tiza, M. F., \& Susanti, F. (2019). Pengaruh Kualitas Pelayanan Terhadap Kepuasan Pelanggan, Studi kasus pada perusahaan JNE Cabang Padang. https://doi.org/10.31227/osf.io/hx87m

Usman, S. Suharyo, W.I., Sulaksono, B. , Mawardi, M.S., , Toyamah, N., dan Akhmadi (2004). Lessons Learned from Microfinance Services In East Nusa Tenggara. SMERU Research Institute Jakarta.

Utami, E.D. dan Setiawan, A.I. (2006). The analysis of BMT's financial performance and internal management: a survey of BMTs in the Banyumas Regency. Journal of Accounting and Finance, 7( 5), 97-114.

Wahibur Rokhman Mirghani, M., Mohammed, M., Bhuiyan, A.A., dan Siwar (2011). Islamic Microcredit and Poverty Allevation in the Muslim World: Prospects and Challages. Australian Journal of Basic and Applied Sciences, 5(9), 620-626.

Wardiwiyono, S (2012). Internal control system for Islamic micro financing:An exploratory study of Baitul Maal wat Tamwil in the City of Yogyakarta Indonesia. International Journal of Islamic and Middle Eastern Finance and Management, 5(4), 340-352.

Widiyanto, M. C. (2007). Effectiveness of Islamic Microcredit Finance in Indonesia. $\mathrm{PhD}$ dissertation submitted to University Putra Malaysia (UPM), Malaysia.

Widiyanto, M.C. dan Ismail, A.G. (2007). Sustainability of BMT financing for developing microenterprises, Working Paper in Islamic Economics and Finance No. WIEF0601, Sumber

http://pkukmweb.ukm.my/,ekonis/BI/working paper.html

Yumna, A.dan Clarke, M. (2012). Integrating zakat and Islamic charities with microfinance initiative in the purpose of poverty alleviation in Indonesia. 8th International Conference on Islamic Economics and Finance, Qatar.

Yusuf, S.A., Amao J.O. dan Olawale, O.T. (2014). Effect of microcredit on small scale enterprises in Osun State, Nigeria. American International journal of Contemporary research, 4(6), 190-200. 